\title{
Spore Trapping and Pathogenicity of Fungi in the Botryosphaeriaceae and Diaporthaceae Associated with Avocado Branch Canker in California
}

\author{
Akif Eskalen, Department of Plant Pathology and Microbiology, University of California, Riverside 92521; Ben Faber, University of \\ California Cooperative Extension, Farm Advisor, Ventura County 93003; and Mary Bianchi, University of California Cooperative \\ Extension, Farm Advisor, San Luis Obispo County 93401
}

\begin{abstract}
Eskalen, A., Faber, B., and Bianchi, M. 2013. Spore trapping and pathogenicity of fungi in the Botryosphaeriaceae and Diaporthaceae associated with avocado branch canker in California. Plant Dis. 97:329-332.

Avocado branch canker in California is caused by a complex of fungal species in the families Botryosphaeriaceae and Diaporthaceae. As the popularity of avocado fruit increases, California growers are under pressure to increase their productivity in order to compete with imports. One way to increase production is through high-density planting, which entails intense canopy management, possibly leaving the trees vulnerable to infection through pruning wounds. A spore trap study was undertaken to determine the seasonal spore discharge of Botryosphaeriaceous and Diaporthaceous fungi. Based on colony counts, the highest population of Botryosphaeriaceous fungi (68\%) occurred during or soon after precipitation events, which coincided with the winter months of December, January, and February. The spring and fall sea-

sons had lower numbers of spores trapped (at 13 and $17 \%$, respectively), with few spores trapped in the summer season. For members of the Diaporthaceae family, spores trapped were almost evenly split between winter and fall seasons (50 and 49\%, respectively), with few to no spores trapped in the spring and summer seasons. A pathogenicity test of six fungi of Botryosphaeriaceae and one fungus of $\mathrm{Di}$ aporthaceae was conducted in the greenhouse. Internal plant vascular lesion lengths resulting from inoculation with any of the seven fungal species differed significantly from the noninoculated control. These studies suggest that pruning during the drier parts of the year would minimize infection by fungi in the Botryosphaeriaceae and Diaporthaceae families.
\end{abstract}

Per capita consumption of avocado fruit in the United States has nearly doubled in the period from 2000 to 2010, and the demand is expected to increase as the nutritional benefits of avocados become more widely known (14). The California avocado industry supplies almost $40 \%$ of this demand, with the rest being supplied by imports from Mexico, Chile, Peru, and New Zealand. To maintain a critical mass of $40 \%$ market share or to increase it, the industry must increase the number of producing acres, increase yields per acre, or both. High-density planting, where the spacing between trees is decreased from 6 by 6 to 3 by $3 \mathrm{~m}$, is one strategy that increases yield per acre (14). High-density planting requires more intensive canopy management, such as more frequent pruning, which may lead to an increased risk for branch canker development.

Members of the Botryosphaeriaceae and Diaporthaceae families are known to cause cankers on a variety of woody hosts such as avocado (Persea americana Mill.), grapevine (Vitis vinifera L.), almond (Prunus dulcis (Mill.) D.A. Webb), citrus (Citrus spp. L.), peach (P. persica (L.) Batsch), plum (25) (Prunus spp. L.), and mango (Magnifera indica L.) $(2,9,21,23,24,28)$. On avocado, one disease initially was known as Dothiorella canker because the fungus isolated was identified as Dothiorella gregaria (7). However, recent research has shown that avocado branch canker is due to a variety of fungal species, of which the most common belong to the Botryosphaeriaceae family and, to a lesser extent, the Diaporthaceae family (11). The fungal pathogens that cause these cankers gain entrance through wounds that can be caused by mechanical means such as pruning, grafting, or girdling and split branches from wind or frost damage (15). If the outer bark is breached by a canker pathogen, infection of the phloem, vascular

Corresponding author: A. Eskalen, E-mail: akif.eskalen@ucr.edu

Accepted for publication 20 August 2012.

http://dx.doi.org/10.1094/PDIS-03-12-0260-RE

(C) 2013 The American Phytopathological Society cambium, and xylem can occur, resulting in disruption in the flow of nutrients, assimilates, and water in the affected branch. This blockage causes weakening and decay of the wood at the infection site, which eventually can lead to wilting or death of the branch (24).

Members of the Botryosphaeriaceae and Diaporthaceae families often produce spores in two types of fruiting bodies called perithecia (ascospores) and pycnidia (conidia), representing the teleomorphic and anamorphic stages of the fungus, respectively. The anamorphic asexual stage of members of the Botryosphaeriaceae family is commonly observed in nature (10) and pycnidia can be observed protruding from the bark in or around the canker tissue as well as on surrounding dead bark and twigs. Perithecia of Botryosphaeriaceae spp. produce ascospores that are known to be wind disseminated (15), whereas conidia ooze out of pycnidia in a ribbon-like gelatinous matrix and are usually disseminated by rain splash (15).

The first objective of this study was to determine the seasonal abundance and distribution of spores of Botryosphaeriaceae and Diaporthaceae spp. released in California avocado groves. The second objective was to evaluate the pathogenicity of Botryosphaeriaceae and Diaporthaceae spp. isolated from avocado branch cankers in a 2008 to 2009 survey (11). Anamorph names will be used for all fungal pathogens described in this study.

\section{Materials and Methods}

Spore trapping. The spore trapping method described by Eskalen and Gubler (6) was utilized for this study, with the following modifications. Traps were placed in eight avocado groves in the major avocado production areas of California during 2008 to 2009 (11). Survey areas included the counties of Riverside, San Diego, Santa Barbara, San Luis Obispo, and Ventura. Two spore traps each were randomly placed on branches between 90 and $180 \mathrm{~cm}$ high, on five trees in each grove. Two 100- $\mu$ l aliquots of slide wash solution were placed on two replicate $85-\mathrm{mm}$-diameter petri plates containing $4 \%$ potato dextrose agar (PDA) (Becton Dickinson and Co.) amended with tetracycline hydrochloride $(0.01 \%$, wt/vol; PDA-tet), which was spread over the petri plates using a sterilized glass rod, and plates were dried for $10 \mathrm{~min}$ inside a laminar flow 
hood. Petri plates were incubated at room temperature $\left(25^{\circ} \mathrm{C}\right)$ and fungal colonies were counted after 7 days. Fungal colonies of Botryosphaeriaceae and Diaporthaceae spp. were identified to family morphologically by colony growth characteristics and subcultured onto fresh PDA-tet. For this study, one colony was assumed to represent one spore. To minimize contamination, traps were changed every 2 weeks and data were combined to report monthly values. Trapping was conducted from September 2008 to August 2009 in Riverside and San Diego Counties, November 2008 to October 2009 in Ventura and Santa Barbara Counties, and March 2009 to February 2010 in San Luis Obispo County.

Pathogenicity study. The pathogenicity of six species of Botryosphaeriaceae (D. iberica, Fusicoccum aesculi, Neofusicoccum australe, N. luteum, N. nonquaesitum, and N. parvum) and one species of Diaporthaceae (Phomopsis sp.) was assessed (Table 1). Isolates were obtained from a field survey carried out between September 2008 and March 2009 (11). Identity of fungal species was determined from morphological studies and the analyses of nucleotide sequence of the internal transcribed spacer and $\beta$-tubulin regions (11).

The greenhouse inoculation method, described by McDonald et al. (12), was used for this study with the following modifications. Two separate pathogenicity trials were conducted on 10 1-year-old avocado seedlings per treatment for trial 1 (in 2009) and 5 avocado seedlings per treatment for trial 2 (in 2010). Inoculum consisted of mycelial plugs from pure cultures, plated on PDA-tet and incubated at $25^{\circ} \mathrm{C}$ for 1 week. Inoculated seedlings were allowed to incubate for 3 months. Plants were arranged in a randomized complete block design. At the end of 3 months, stems were cut and rinsed with distilled water. To examine the internal vascular discoloration, outer stem tissue was peeled off and discoloration was measured upward and downward from the point of inoculation. Small pieces $(0.5 \mathrm{~cm})$ of necrotic tissue from the edge of each lesion were cut and placed on PDA-tet petri plates to recover the inoculated fungus and complete Koch's postulates.

Two-way analysis of variance (ANOVA) in SAS (version 9.3; SAS Institute) was performed to assess differences in the extent of vascular discoloration. To satisfy the assumptions of the ANOVA, the $\log _{10}$ transformation of the data was used. The Waller-Duncan $K$-ratio $t$ test was used for comparison of treatment means at $P<$ 0.05 .

\section{Results}

Spore trapping. Overall, recovery of spores in the families Botryosphaeriaceae and Diaporthaceae occurred during or soon after a rain event (Fig. 1). Total rainfall was highest in the months of December, January, or February. The number of spores of Botryosphaeriaceae spp. trapped was 68,13 , and $17 \%$ during the winter (December, January, and February), spring (March, April, and May), and fall (September, October, and November) seasons, respectively. The summer season (June, July, and August) had the lowest level of Botryosphaeriaceae spores trapped, at 2\%. Spores of Diaporthaceae spp. trapped were almost evenly split between the winter and fall seasons, at 50 and $49 \%$, respectively, with few to no spores trapped in the spring and summer seasons (Fig. 1).

Pathogenicity study. After 3 months, outer wound symptoms were visible as thickening and splitting of the outer stem tissue at the inoculation site, with the inoculation wounds increasing in size from 4 by $4 \mathrm{~mm}$ up to 32 by $15 \mathrm{~mm}$. An open, oozing canker developed at the inoculation site, with sap exudate drying to a whitish-beige powder overlying the wound. Peeling away outer stem tissue revealed dark vascular lesions extending upward and downward from the inoculation site. In contrast, the control treatment developed a dry, closed, woody canker over the inoculation site, with no exudate.

All seven fungal species inoculated onto avocado seedlings differed significantly from the control (Fig. 2). Vascular lesion lengths varied from 3.7 to $7.8 \mathrm{~cm}$. N. nonquaesitum was significantly different from $N$. australe and D. iberica. There were no significant differences in vascular lesion length between $N$. nonquaesitum, $N$. luteum, N. parvum, F. aesculi, and the Phomopsis sp. N. nonquaesitum is a recently described species in the family Botryosphaeriaceae (9) and produced the longest lesion length of the seven fungi tested. Koch's postulates were completed, with each species consistently reisolated from inoculated seedlings.

\section{Discussion}

Spore trapping. The rainy season in California extends approximately from November to April, with the heaviest rainfall usually occurring from December to February. Our spore trap study shows that spore trapping of Botryosphaeriaceae and Diaporthaceae spp. occurred most frequently during the months with the highest precipitation (Fig. 1). This was consistent with other spore trap studies in California vineyards $(6,26)$ monitoring the release of spores of Botryosphaeriaceae spp. (the cause of dieback) and the release of spores of Phaeomoniella and Phaeoacremonium spp. (the cause of esca or black measles). Both studies showed the greatest spore release during and following rain events.

Although humidity can stimulate spores to ooze from the pycnidia (16), the actual dispersal of these spores requires the impact of water droplets either naturally via rain splash or artificially via sprinkler irrigation. A previous study on pistachio showed Botryosphaeria dothidea (F. aesculi) to be a splash-dispersed pathogen (3) and, by simply lowering the trajectory of the sprinklers, panicle and shoot blight were reduced (16). These results agree with our spore trap study, in which most of the spores captured were captured during the rainy season. This result could not be associated with the irrigation practices, because the water trajectory by the sprinkler system was low and did not come into contact with the canopy. Other studies have suggested that birds, insects, and wind could be involved in spore dissemination of species in the Botryosphaeriaceae family in vineyards $(3,16)$, which could explain the negligible amount of spores captured during the dry season.

As mentioned, cultural practices that break the outer bark and could lead to infection by splash-dispersed pathogens include pruning, grafting, girdling, and phosphonate injection. Increased interest in high-density planting of avocado in California requires intensive canopy management, such as pruning, thereby increasing the risk for canker development. Grafting young trees or top-worked stumps can lead to infection, with a canker forming around the graft union (15). Girdling is a common practice to increase productivity in many fruit trees and involves cutting through and removing the bark in a circular pattern around the branch (13). This practice is usually done in October and may increase the risk for

Table 1. Isolates used in the pathogenicity study

\begin{tabular}{lccc}
\hline Species & Isolate & GenBank number $^{\mathbf{a}}$ & Isolate number $^{\mathbf{b}}$ \\
\hline Dothiorella iberica & UCR452 & HQ529753 & CBS 133500 \\
Fusicoccum aesculi & UCR453 & HQ529750 & CBS 133325 \\
Neofusicoccum nonquaesitum & UCR532 & HQ529771 & CBS 133501 \\
N. luteum & UCR211 & GQ857658 & CBS 133502 \\
N. parvum & UCR295 & HQ529765 & CBS 133503 \\
N. australe & UCR160 & HQ529741 & CBS 133326 \\
Phomopsis sp. & UCR535 & KC294575 & CBS 134091 \\
\hline
\end{tabular}

a Internal transcribed spacer.

${ }^{\mathrm{b}} \mathrm{CBS}=$ The Centraalbureau voor Schimmelcultures, Netherlands. 
pathogen infection if the wound does not heal by the onset of the rainy season. Phosphonate injections are used to manage Phytophthora root rot. For maximum effectiveness, injections are recommended when foliar flushes are $75 \%$ complete (15), which is approximately in late spring (May) and summer (August). Our results indicate that any activity during the rainy winter months that breaks the outer bark should be avoided. In addition, protecting wounds with a fungicide application may prevent invasion by canker-causing pathogens, as has been shown in other studies (20).

Pathogenicity study. Perennial cankers on avocado have a long history in California and were originally thought to be caused primarily by Dothiorella spp. Recent phylogenetic research has shown branch cankers to be caused by a complex of species in the families Botryosphaeriaceae and Diaporthaceae (11). This study of the pathogenicity of six species of Botryosphaeriaceae and one species of Diaporthaceae has shown that all are pathogenic on avocado and individually capable of causing canker and vascular discoloration.

The species resulting in the longest lesion length, $N$. nonquaesitum, was recently isolated from cankers of almond, California bay laurel, and Chilean blueberry (9) and is closely related to N. parvum (11). Because it is a relatively newly described species, knowledge of its host range and distribution is lacking. In a field virulence assay on almond trees, $N$. nonquaesitum was found to produce lesions on 1-year-old branches (9). These results are similar to the present study.
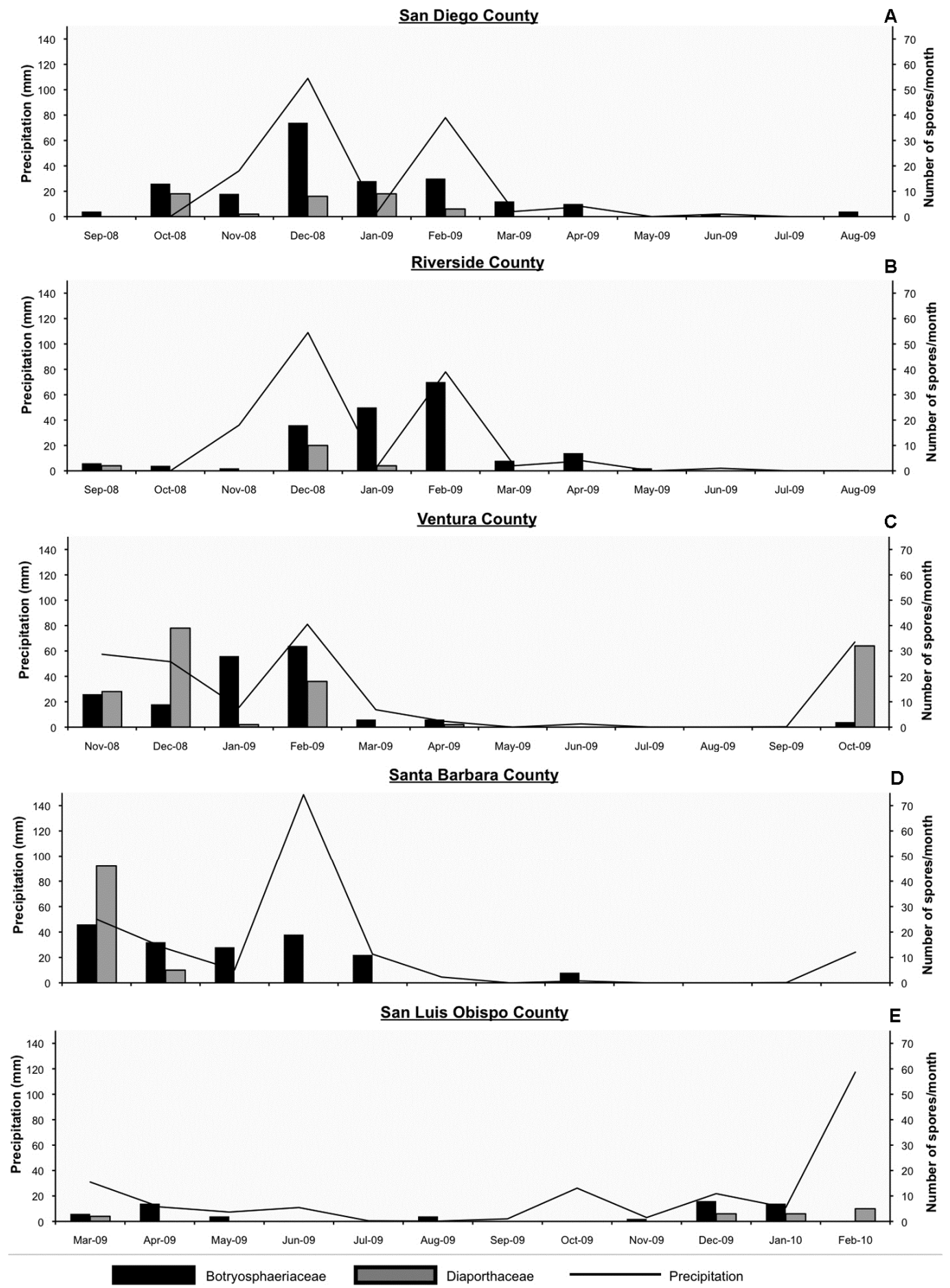

Fig. 1. Total number of spores of Botryosphaeriaceae and Diaporthaceae trapped per month correlated with monthly precipitation (mm) in A, San Diego; B, Riverside; C, Ventura; D, Santa Barbara; and E, San Luis Obispo counties. 


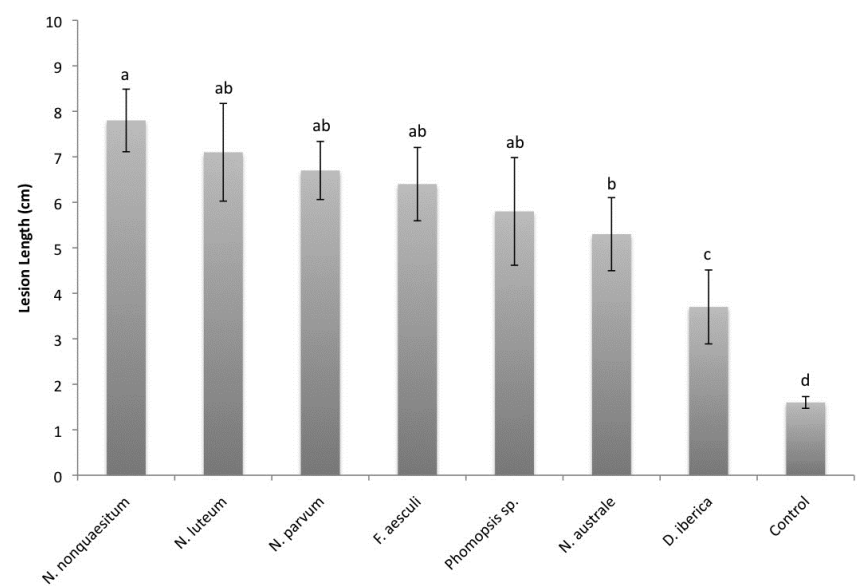

Fig. 2. Mean vascular lesion lengths of six isolates of Botryosphaeriaceae and one isolate of Diaporthaceae on 1-year-old 'Hass' avocado, 2009 to 2011. Each bar represents the mean of 15 avocado seedlings. Means with the same letter are not significantly different at the 0.05 probability level using the Waller-Duncan $k$-ratio $t$ test.

The remaining Botryosphaeriaceae spp. described below are all considered to have wide geographical distributions on multiple woody hosts. $N$. australe, $N$. luteum, and $N$. parvum were first reported in connection with avocado canker in California in 2009 (12). N. parvum has been previously reported to cause canker and dieback on avocado in Chile (15) and Spain (30). N. luteum was first described as a species in 1985 by Pennycook and Samuels (17), who isolated it from kiwifruit in New Zealand. $N$. australe was first described as a species in 2004 (22), when slight morphologic and gene sequence variations indicated that it was a distinct species closely related to $N$. luteum. $N$. australe is considered to have originated in Australia (22), where it has been isolated from various native and cultivated hosts. From Australia, it is thought to have been introduced into other countries in the northern hemisphere on exports of commercial host species. In California, both $N$. luteum and $N$. australe have also been reported on grapevine (28).

$F$. aesculi is the anamorph of the type species of the genus Botryosphaeria (B. dothidea) $(5,18,19)$. In addition to avocado, $F$. aesculi has been found to be pathogenic on a wide range of hosts in California, both native and cultivated $(4,9,27)$.

Members of the Diaporthaceae family were the second most abundant family of fungal pathogens isolated from the avocado branch canker survey (11). Species of Phomopsis are anamorphs of Diaporthe within this family and are known to have a widespread distribution on a large number of hosts. They can cause a variety of diseases such as cankers, diebacks, rots, spots, and wilts $(1,29)$. On avocado, they have been reported to be a minor cause of postharvest rot (8). Isolates of a Phomopsis sp. recovered in this study did not resolve with known species after preliminary phylogenetic analyses. There is considerable overlap of morphological characters between species of Phomopsis (21) and, therefore, further studies are required to identify this species of Phomopsis.

\section{Acknowledgments}

We thank the California Avocado Commission and its members for funding and supporting this research; M. Mochizuki, A. Breschini, and M. Tapia for assistance with the spore trap study; D. Wang, J. Mayorquin, J. Lee, L. Yeung, and T. Cheung for assistance in the lab and greenhouse; and S. Lynch for assistance with technical editing and feedback.

\section{Literature Cited}

1. Adaskaveg, J. E., Forster, H., and Connel, J. H. 1999. First report of fruit rot and associated branch dieback of almond in California caused by a Phomopsis species tentatively identified as $P$. amygdali. Plant Dis. 83:1073.

2. Adesemoye, A. O., and Eskalen, A. 2011. First report of Spencermartinsia viticola, Neofusicoccum australe, and $N$. parvum causing branch canker of citrus in California. Plant Dis. 95:770-770.

3. Ahimera, N., Gisler, S., Morgan, D. P., and Michailides, T. J. 2004. Effects of single-drop impactions and natural and simulated rains on the dispersal of Botryosphaeria dothidea conidia. Phytopathology 94:1189-1197.

4. Brooks, F. E., and Ferrin, D. M. 1994. Branch dieback of southern Califor- nia chaparral vegetation caused by Botryosphaeria dothidea. Phytopathology 84:78-83

5. Crous, P. W., Slippers, B., Wingfield, M. J., Rheeder, J., Marasas, W. F. O., Philips, A. J. L., Alves, A., Burgess, T., Barber, P., and Groenewald, J. Z. 2006. Phylogenetic lineages in the Botryosphaeriaceae. Stud. Mycol. 55:235-253.

6. Eskalen, A., and Gubler, W. 2001. Association of spores of Phaeomoniella chlamydospora, Phaeoacremonium inflatipes, and Pm. aleophilum with grapevine cordons in California. Phytopathol. Mediterr. 40:429-432.

7. Halma, F. F., and Zentmyer, G. A. 1953. Relative susceptibility of Guatemalan and Mexican avocado varieties to Dothiorella canker. Calif. Avocado Soc. Yearb. 38:156-158.

8. Hartill, W. F. T., and Everett, K. R. 2002. Inoculum sources and infection pathways of pathogens causing stem-end rots of 'Hass' avocado (Persea americana). N. Z. J. Crop Hortic. Sci. 30:249-260.

9. Inderbitzin, P., Bostock, R. M., Trouillas, F. P., and Michailides, T. J. 2010. A six locus phylogeny reveals high species diversity in Botryosphaeriaceae from California almond. Mycologia 102:1350-1368.

10. Jacobs, K. A., and Rehner, S. A. 1998. Comparison of cultural and morphological characters and ITS sequences in anamorphs of Botryosphaeria and related taxa. Mycologia 90:601-610.

11. McDonald, V., and Eskalen, A. 2011. Botryosphaeriaceae species associated with avocado branch cankers in California. Plant Dis. 95:1465-1473.

12. McDonald, V., Lynch, S., and Eskalen, A. 2009. First report of Neofusicoccum australe, N. luteum, and $N$. parvum associated with avocado branch canker in California. Plant Dis. 93:967-967.

13. McNeil, R., and Parsons, G. 2003. Girdling of Hass avocado trees to increase fruit yield and income in "off" years in a California coastal valley. Proc. World Avocado Congress, Granada-Malaga, Spain.

14. Melban, K. 2011. Issues Watch: Maximizing Grower Returns. Grove 1:16-18.

15. Menge, J., and Ploetz, R. C. 2003. Diseases of avocado. Pages 35-71 in: Diseases of Tropical Fruit Crops. R. C. Ploetz, ed. CABI Publishing, Wallingford, UK.

16. Michailides, T. J., and Morgan, D. P. 1993. Spore release by Botryosphaeria dothidea in pistachio orchards and disease control by altering the trajectory angle of sprinklers. Phytopathology 83:145-152.

17. Pennycook, S. R., and Samuels, G. J. 1985. Botryosphaeria and Fusicoccum species associated with ripe fruit rot of Actinidia deliciosa (kiwifruit) in New Zealand. Mycotaxon 24:445-458.

18. Phillips, A. J. L., Alves, A., Correia, A., and Luque, J. 2005. Two new species of Botryosphaeria with brown, 1-septate ascospores and Dothiorella anamorphs. Mycologia 97:513-529.

19. Phillips, A. J. L., Alves, A., Pennycook, S. R., Johnston, P. R., Ramaley, A., Akulov, A., and Crous, P. W. 2008. Resolving the phylogenetic and taxonomic status of dark-spored teleomorph genera in the Botryosphaeriaceae. Persoonia 21:29-55.

20. Rolshausen, P. E., Urbez-Torres, J. R., Rooney-Latham, S., Eskalen, A., Smith, R .J., and Gubler, W. D. 2010. Evaluation of pruning wound susceptibility and protection against fungi associated with grapevine trunk diseases. Am. J. Enol. Vitic. 61:113-119.

21. Santos, J. M., and Phillips, A. J. L. 2009. Resolving the complex of $\mathrm{Di}$ aporthe (Phomopsis) species occurring on Foeniculum vulgare in Portugal. Fungal Divers. 34:111-125.

22. Slippers, B., Fourie, G., Crous, P. W., Coutinho, T. A., Wingfield, B. D., and Wingfield, M. J. 2004. Multiple gene sequences delimit Botryosphaeria australis sp. nov. from B. lutea. Mycologia 96:1030-1041.

23. Slippers, B., Johnson, G. I., Crous, P. W., Coutinho, T. A., Wingfield, B. D. and Wingfield, M. J. 2005. Phylogenetic and morphological re-evaluation of the Botryosphaeria species causing diseases of Magnifera indica. Mycologia 97:99-110.

24. Slippers, B., Smit, W. A., Crous, P. W., Coutinho, T. A., Wingfield, B. D., and Wingfield, M. J. 2007. Taxonomy, phylogeny and identification of Botryosphaeriaceae associated with pome and stone fruit trees in South Africa and other regions of the world. Plant Pathol. 56:128-139.

25. Tisserat, N. A. 2004. Canker Diseases of Trees. Kansas State University Agricultural Experiment Station and Cooperative Extension Service, Kansas State University.

26. Urbez-Torres, J. R., Battany, M., Bettiga, L. J., Gispert, C., McGourty, G. Roncoroni, J., Smith, R. J., Verdegaal, P., and Gubler, W. D. 2010. Botryosphaeriaceae species spore-trapping studies in California vineyards. Plant Dis. 94:717-724.

27. Urbez-Torres, J. R., and Gubler, W. D. 2009. Pathogenicity of Botryosphaeriaceae species isolated from grapevine cankers in California. Plant Dis. 93:584-592.

28. Urbez-Torres, J. R., Leavitt, G. M., Voegel, T. M., and Gubler, W. D. 2006 Identification and distribution of Botryosphaeria spp. associated with grapevine cankers in California. Plant Dis. 90:1490-1503.

29. Weingartner, D. P., and Klos, E. J. 1974. Etiology and symptomatology of canker and dieback diseases on highbush blueberries caused by Gordonia (Fusicoccum) cassandrae and Diaporthe (Phomopsis) vaccinii. Phytopathology 65:105-110.

30. Zea-Bonilla, T., Gonzalez-Sanchez, M. A., Martin-Sanchez, P. M., and Perez-Jimenez, R. M. 2007. Avocado dieback caused by Neofusicoccum parvum in the Andalucía Region, Spain. Plant Dis. 91:1052-1052. 